\title{
СТУДЕНТСЬКА ОЛІМПІАДА ЯК УМОВА ФОРМУВАННЯ ФАХІВЦЯ
}

\author{
Л. М. Унгурян, О. А. Мельник, І. А. Науменко \\ Одеський національний медичний університет
}

\section{STUDENT OLYMPIAD AS A CONDITION OF FORMING OF SPECIALIST

\author{
L. M. Unhuryan, O. A. Melnyk, I. A. Naumenko \\ Odessa National Medical University
}

\begin{abstract}
Одним із засобів формування студентів як фахівців є Всеукраӥнська студентська олімпіада (ВСО) - змагання студентів в творчому застосуванні знань і умінь 3 дисциплін, що вивчаються у вищому навчальному закладі. Вона проводиться 3 метою вдосконалення якості підготовки фахівців, а також для підвищення інтересу студентів до вибраної професії, виявлення обдарованої молоді і формування кадрового потенціалу.

One of facilities of forming of students as specialists there is All-Ukrainian Student Olympiad (VSO) - competition of students in creative application of knowledges and abilities on disciplines which are studied in higher educational establishment. It is conducted with the purpose of perfection of quality of preparation of specialists, and also for the increase of interest of students to the chosen profession, exposure of the gifted young people forming of skilled potential.
\end{abstract}

Вступ. Однією з важливих проблем сучасної професійної освіти є пошук і розробка нових методів підготовки фахівців.

Робота з обдарованими дітьми є одним з пріоритетних напрямів молодіжної державної політики. Олімпіади - одна із загальновизнаних форм роботи з обдарованими студентами. Участь в олімпіаді відіграє велику роль у справі виховання молодих людей і формує такі важливі особові якості, як відповідальність за почату справу, цілеспрямованість, працьовитість. Це завдання успішно вирішується при навчанні в умовах олімпіадного середовища - одного з основних навчальних процесів єдиної методичної системи.

Всеукраїнська студентська фармацевтична олімпіада - система очних змагань студентів вищих медичних і фармацевтичних, а також технологічних навчальних закладів, в ході яких проводиться оцінка рівня знань і підготовки студентів-учасників зі спеціальностей “Фармація”, “Технологія фармацевтичного виробництва” і на конкурсній основі визначаються переможці.

Основними цілями олімпіади є:

- підвищення престижу спеціальностей “Фармація”

i “Технологія фармацевтичного виробництва”;

- стимулювання мотивації студентів до оволодіння знаннями, уміннями і навиками при отриманні вказаних спеціальностей;

- сприяння розвитку соціального партнерства підприємств галузі і вузів.
Завданнями олімпіади є:

- виявлення якісного рівня підготовки; уміння застосовувати знання і навички по дисциплінах, що вивчаються; загальний рівень готовності фахівців, що випускаються до професійної діяльності;

- виявлення перспективних кадрів фармацевтичних спеціальностей, стимулювання їх наукової діяльності, організація роботи профорієнтації і сприяння зайнятості молодих фахівців-випускників.

Основна частина. Всеукраїнська студентська олімпіада (ВСО) є одним із засобів формування студентів як фахівців. Студенти змагаються в творчому застосуванні знань і умінь 3 дисциплін, що вивчаються у вищому навчальному закладі. Вона проводиться 3 метою вдосконалення якості підготовки фахівців, а також для підвищення інтересу студентів до вибраної професії, виявлення обдарованої молоді і формування кадрового потенціалу.

Олімпіада проводиться в два тури протягом календарного року: перший тур - внутрішньовузівський, другий - всеукраїнський (міжрегіональний). Кожен тур олімпіади включає єдину тріаду етапів ії проведення: підготовку учасників до виступу, проведення олімпіади, аналіз виступу. Найбільш важливим є етап підготування до ВСО.

Як завжди, олімпіада проходить у два етапи: теоретичний і практичний, до складу журі входять керівники всіх делегацій. Олімпіада за спеціальністю “Фармація” - комплексна, об'єднує всі шість дис-

(ㄷ Л. М. Унгурян, О. А. Мельник, І. А. Науменко 
циплін-складових спеціальності. У порівнянні з моноолімпіадами це інтелектуальне змагання значно складніше, але більш показове.

ВСО включає спеціальні дисципліни:

- 3 фармакогнозії - встановлення достовірності і оцінка якості лікарської рослинної сировини;

- з управління і економіки фармації на знання нормативної бази і механізмів фармацевтичного маркетингу;

- 3 аптечної технології - виготовлення екстемпоральної лікарської форми;

- з фармацевтичної хімії-на знання властивостей лікарських субстанцій і сучасної приладової бази для оцінки якості субстанції.

Історія проведення Всеукраїнської студентської олімпіади 3 фармації нараховує вже майже півтора десятиліття. Вперше вона три роки поспіль проходила на базі НФаУ, далі тричі у Запоріжжі, потім - у Львові, останні три роки знову відбувається на базі НФаУ, а цього року буде проводитися в Тернополі.

Неможливо забезпечити хороший виступ команди і окремих її учасників, а також вирішити інші завдання навчання, якщо цілеспрямовано не займатися їх підготовкою. Проте на практиці найчастіше викладачі обмежуються тільки виявленням і відбором найбільш здатних студентів. На наш погляд, це неправильно, оскільки у разі невдалого виступу студент може отримати важку психологічну травму, яка може позначитися на його подальшій освітній і професійній діяльності. У зв'язку з цим необхідна методична система по забезпеченню підготовчого етапу.

Сформулюємо їі основні принципи:

1. Принцип фундаментальності знань. Оскільки мова йде про підготовку студентів до предметних олімпіад і конкурсів за фахом, то володіння знаннями, уміннями і навиками у сфері спеціальних дисциплін стає обов' язковою умовою успіху виступу, закріплення цих знань при вирішенні практичних завдань.

2. Принцип міжпредметних зв'язків і розвитку отриманих знань. Так, наприклад, олімпіада з фармації вимагає знань технології лікарських форм, фармацевтичної хімії, фармакогнозії, організації і економіки фармації, фармакології і виконання представлених на олімпіаді завдань вимагає використання всього об'єму попередніх знань.

3. Принцип максимальної самостійності. Найміцніші знання - це ті, які студент отримує в процесі самостійної роботи. Правильне рішення задачі, отримане самостійно, нехай навіть іноді не через повне логічне обгрунтування, надалі при остаточному колективному обговоренні і аналізі результату не тільки набуде ясної переконливої форми і збереже в пам'яті новий спосіб рішення, але і забезпечить упевненість у своїх силах.

4. Принцип активності знань. Однією з особливостей олімпіад $\epsilon$ те, що весь запас знань і умінь учасника знаходиться в постійному активі, оскільки олімпіадні завдання складаються з урахуванням всіх накопичених знань, при цьому не тільки з однієї даної дисципліни.

5. Принцип дієвості знань. Особливо значимий при проведенні конкурсів за фахом, в програму яких включаються практичні завдання. Уміння матеріалізувати отримані знання - одне з головних завдань навчання.

6. Принцип додаткових знань. При навчанні деякі теми і навіть цілі розділи часто розглядаються поверхнево або їх вивчення не передбачене навчальною програмою зовсім, незважаючи на їх важливість не тільки для освоєння безпосередньо дисципліни, але і для майбутньої професійної діяльності. В цьому випадку вивчення таких тем в рамках наукових кружків дозволяє раціонально коректувати освітні програми.

7. Принцип випереджаючого рівня складності завдань. Його суть полягає в наданні студентам при підготовці до олімпіади певного туру можливості вирішення завдань, які за складністю відповідають вищому статусу. Ефективність цього принципу багато разів підтверджувалася на практиці і не тільки при олімпіадній підготовці.

8. Принцип комплексного аналізу виконуваних завдань. Цей принцип сприяє виробленню навиків по рішенню завдань підвищеної складності, глибшому вивченню предмета, формуванню творчого аналітичного мислення і здатності до майбутньої фармацевтичної діяльності. Він реалізується за рахунок виявлення багатоваріантності виконання завдання і вибору найбільш раціонального 3 них.

9. Аналіз результатів минулих олімпіад. Аналізується ступінь вирішеності завдань попередніх олімпіад, виявляються недоліки, а також нові способи вирішення відомих завдань. Це також сприяє зміцненню знань, умінь, навиків.

10. Принцип спадкоємності знань. Полягає не тільки в послідовному накопиченні знань учасниками олімпіад і конкурсів, але і в активному використанні ними знань, отриманих у всіх навчальних процесах (навчання у вузі, навчально-виробнича практика, професійне і особисте спілкування).

11. Принцип безперервності отримання знань. Припускає цілеспрямоване навчання студентів починаючи з 1-го курсу уміння мислити творчо, нешаблон- 
но, самостійно, розвиток у них інтуїції, здібностей до абстрагування.

Конкурсний етап ВСО полягає у виконанні учасниками різних завдань, що включають вирішення теоретичних і експериментальних завдань, практичні завдання, тестування тощо. Всі завдання виконуються самостійно, в умовах обмеженого часу, в незвичній обстановці, в стані хвилювання за свою команду.

Висновок. Таким чином, вищеперелічені умови,

\section{Література}

1. Гудзинский А. О. Социальный механизм управления инновационным университетом: автореф. дисс. д-ра соц. наук : 22.00.08 / Гудзинский Александр Олегович. - СПб., 2005. $-354 \mathrm{c}$.

2. Морозова А. В. Управление процессом профессиональной социализации студентов вузов в условиях модернизации институтов образования : монография / А. В. Морозова, Н. А. Фролова. -Орел : Изд-во ОРАГС, 2005. - 200 с.

3. Наумкин Н. И. Инновационные методы обучения в вузе / Н. И. Наумкин. - Саранск, 2008.

4. Прокопенко І. Ф. Педагогічні технології : навчальний вимоги і принципи спільно з практичною підготовкою при врахуванні психолого-методичних особливостей складають в цілому методичну систему формування у студентів здатності до інноваційної діяльності в умовах олімпіадного середовища, яке є невід'ємною частиною навчального процесу. Висока ефективність іiї використання підтверджується перемогами на олімпіадах і конкурсах, а також практичною роботою студентів по розробці інноваційних продуктів.

посібник / I. Ф. Прокопенко, В. І. Свдокимов. - Харків : Колегіум, 2005. - 224 с.

5. Ребрин О. Смешанное обучение / О. Ребрин, И. Шолина, А. Сысков // Высшее образование в России. - 2005. №8.

6. Трушкова И. Гуманитарные технологии в образовании / И. Трушкова // Высшее образование в России. - 2006. -№ 3 .

7. Шагеева Ф. Современные образовательные технологии / Ф. Шагеева, В. Иванов // Высшее образование в России. - 2006. - № 4 . 